\title{
What a woodchuck could chuck
}

\author{
by Monica Harrington
}

\section{SCIENTIFIC NAME \\ Marmota monax}

\section{TAXONOMY}

PHYLUM: Chordata

CLASS: Mammalia

ORDER: Rodentia

FAMILY: Sciuridae

\section{Physical description}

The woodchuck, also called groundhog, land beaver, mouse bear or whistle-pig, is a type of marmot or large ground squirrel found primarily in lowland areas of North America. Its short, strong limbs and curved, thick claws are well-suited to digging and burrowing, one of the woodchuck's main activities in the wild. It also sports rounded ears that can close off the ear canal to prevent dirt and debris from entering it while burrowing underground.

\section{Burrowing behavior}

Woodchucks sleep, care for their young and hibernate underground, and their burrows can be vast, with tunnels extending more than $15 \mathrm{~m}$ in length and including multiple access points. It has been estimated that a woodchuck displaces over $300 \mathrm{~kg}$ of soil in digging an average burrow. In residential and agricultural areas, woodchuck burrows are considered a nuisance or even a hazard, as they can destroy crops, damage farming equipment and compromise building foundations ${ }^{1}$. But they can have unexpected benefits too. Woodchuck burrows in Ohio have turned up numerous historical artifacts, including bones, pottery and pieces of stone, leading to the identification of an archaeological site called the Ufferman Site ${ }^{2}$.

\section{Research résumé}

Woodchucks have been used to study a broad range of biomedical research topics including obesity and energy balance, endocrine and metabolic function, central nervous system control mechanisms, and cardiovascular and cerebrovascular disease ${ }^{3}$. They are also commonly used in hibernation research. One recent study examined the mechanisms that protect cardiac function during hibernation in woodchucks in hopes of gaining information that could help to prevent cardiac dysfunction resulting from hypothermic stress and myocardial ischemia in humans ${ }^{4}$. The 'optimization' of hibernation strategies-balancing the physiological and ecological costs against the benefits-has also been examined in woodchucks. Researchers found that woodchucks' body mass correlated positively with body temperature during torpor and correlated negatively with the fraction of time spent in torpor, meaning that larger woodchucks spent less time in torpor and at higher body temperatures than smaller woodchucks ${ }^{5}$. The scientists suggest that this strategy may improve the woodchucks' chances of success in defending territories, avoiding predators and reproducing when they emerge from hibernation.

The biggest contribution woodchucks have made to biomedical research is arguably in the area of hepatitis and liver cancer. Woodchucks are naturally susceptible to infection with hepatitis virus. Once infected, they develop liver cancer. This pattern is very similar to hepatitis $B$ virus infection and subsequent development of hepatocellular carcinoma in humans, making the woodchuck a valuable model for investigating virology, immunology and treatment of these diseases ${ }^{6}$. The woodchuck model has provided insight into the roles of persistent hepatitis virus infection, viral load and host immune response in chronic hepatitis and hepatocellular carcinoma ${ }^{7}$. The model is also suitable for evaluating the safety and efficacy of candidate drugs and experimental vaccines for treating and preventing the diseases that result from

hepatitis virus infection ${ }^{7}$. Initial studies relied on wild-caught woodchucks, but since then, breeding colonies have been established in laboratories; both wild-caught and captive-born woodchucks are also available commercially (http://www.northeasternwildlife.com/).

1. Bollengier, R.M. Jr. in Prevention and Control of Wildlife Damage (eds. Hygnstrom, S.E., Timm, R.M. \& Larson, G.E.) B-183-B-187 (University of Nebraska, Lincoln, NE, 1994). <http://icwdm.org/handbook/allPDF/ Rodentcomplete.pdf>

2. Owen, L.K. (ed.) Dictionary of Ohio Historic Places vol. 1 (Somerset Publishers, Inc., St. Clair Shores, MI, 1999).

3. Young, R.A. \& Sims, E.A. The woodchuck, Marmota monax, as a laboratory animal. Lab. Anim. Sci. 29, 770-780 (1979).

4. Li, H. et al. Proteomic mechanisms of cardioprotection during mammalian hibernation in woodchucks, Marmota monax. J. Proteome Res. 12, 4221-4229 (2013).

5. Zervanos, S.M., Maher, C.R. \& Florant, G.L. Effect of body mass on hibernation strategies of woodchucks (Marmota monax). Integr. Comp. Biol. doi:10.1093/icb/ict100 (published online 16 December 2013).

6. Tennant, B.C. \& Gerin, J.L. The woodchuck model of hepatitis B virus infection. ILAR J. 42, 89-102 (2001).

7. Menne, S. \& Cote, P.J. The woodchuck as an animal model for pathogenesis and therapy of chronic hepatitis B virus infection. World J. Gastroenterol. 13, 104-124 (2007). 